\title{
Plant iconography and its message: realism and symbolic message in the Bernini fountain of the four rivers in Rome
}

\author{
G. Caneva ${ }^{1}$ (D) A. Altieri ${ }^{2} \cdot$ A. Kumbaric ${ }^{1} \cdot$ F. Bartoli $^{1}$ (D)
}

Received: 13 June 2020 / Accepted: 1 August 2020 / Published online: 19 August 2020

(c) The Author(s) 2020

\begin{abstract}
The use of symbols in architecture of the past centuries is evident, even if sometimes cryptic. The reasons behind the representation of plants in artistic and architectural contexts are of great interest as they help in their understanding. We analysed the plants carved in the Fountain of Four Rivers (Rome), designed by G.L. Bernini (mid-seventeenth century), through iconographic and historical documents. The carved plants (about 34 species) creates a natural and symbolic association with the selected rivers and continents. Some species are chosen to characterise various geographic contexts or fluvial and rupestrian habitats or are referred to the papal coats of arms (Innocent X Pamphilj). A certain number has auspicious connotation and takes a strong symbolic salvific meaning and protective against the evil's threat. The Kircherian influence emerges in several iconographic choices, as well as the river selection and orientation, in a philosophical-religious logic linked to the Papacy and Christianity role.
\end{abstract}

Keywords Phytoiconology $\cdot$ Plant symbolism $\cdot$ Baroque fountain $\cdot$ Flora representation $\cdot$ Plant and sculpture

\section{Introduction}

Plants in architecture are often interpreted for their decorative functions. Indeed, the use of symbols in architecture of the past century is evident, even if sometimes cryptic (De Naeyer 2019). The portrayal of plants in art can take on various functions which vary in relation to the purpose of the work itself and the historical period to which it belongs (Moggi 1987; Pacini 1995; Caneva et al. 2005). In particular, the type, meaning and method of representation are elements of particular significance when interpreting the intention of their inclusion in a work of art (Mattirolo 1911; Levi D'Ancona 1977; Mangiavacchi and Pacini 2002; Franchi and Pacini 2017).

The symbolic intent, i.e. that of a connection with the transcendent meanings of the object of representation itself was predominant in ancient times (Baumann 1993, 2000; Amigues 2002; Caneva and Bohuny 2003; Caneva 2010;

\section{F. Bartoli}

flavia.bartoli@uniroma3.it

1 Department of Science, University Roma Tre, Viale G. Marconi 446, 00146 Rome, Italy

2 Istituto Superiore per la Conservazione e Restauro, via di S. Michele 23, Rome, Italy
Caneva et al. 2014; Kumbaric and Caneva 2014), in the Middle Ages (Baltrušaitis 1993; Kandeler 2006; Kandeler and Ulrich 2009a, b, c, d, e, f, g, h, i, j; Signorini et al. 2011, 2017; Signorini and Zucchi 2018; Metusala et al. 2020), in the Renaissance and up to the Age of Enlightenment (Levi D'Ancona 1977; Janick and Caneva 2005; Kandeler and Ulrich 2009a, b, c, d, e, f, g, h, i, j; Fărcaş et al. 2015; Savo et al. 2016). This connection was due to magical-religious beliefs attributed to plants as an expression of the gods or divine will found in classical texts (Plinius 1985) and in those of sacred iconology (Ripa 1603; Bianchi 1987). On a symbolic-allegorical level, this is attributable to a form of thought that tends to create associative models that represent archetypes common to several cultures (Jung and Kereny 1942; Jung 1983). From the eighteenth century onwards, the arrival of modern pharmacological studies applied to medicine finally led to a loss of the transcendental background of symbolism in the twentieth century (Kandeler and Ulrich 2009a, b, c, d, e, f, g, h, i, j).

Certainly, in works of art, the decorative function of embellishment or harmonious balance of the work itself is always present, especially in the portrayal of flora (Mosco and Rizzotto 1988; Caneva and Carpaneto 2011; Sgamellotti and Caneva 2017). Similarly, a purely descriptive function (Baldini et al. 1982; Nepi and Signorini 2015) can also be 
evident since plants are fundamental elements in contextualising a landscape (Agnoletti and Signorini 2011). Subsequently, from the Renaissance onwards, a purely naturalistic-scientific function of faithful representation of species diversity in nature is also apparent (Pacini 1988; Caneva et al. 2005).

Hence, there are three concepts that guide artists in the portrayal of plants: the real, the ideal and the symbolic, not thereby excluding any combined and interconnected intent (Pacini 1995). An iconographic study aimed at scientifically defining plant species represented in works of art is often contextualised in artistic monographs to better understand the subjects represented (Moggi 1982; Caneva 1992; Caneva and Carpaneto 2011; Franchi and Pacini 2017; Clauser et al. 2018). They should not be seen as pure exercises in style but rather as a useful tool in interpreting a work of art and also as a valid support in restoration interventions (Caneva and Dinelli 1991). Indeed, many studies to date have primarily concentrated on the medieval and Renaissance periods, whereas botanical motifs were endowed with a host of polysemic meanings, particularly in the sophisticated cultural ambience of seventeenth-century Europe.

In this context, the study of the plant iconography of the Fountain of the Four Rivers in Rome, designed by Gian Lorenzo Bernini in the mid-seventeenth century, is of particular importance, not only for its very high historical and artistic value, but also for the indisputable complexity of the work. It was commissioned by Pope Innocent X Pamphilj and is located in the centre of one of the most evocative squares of the city (Piazza Navona), which was built upon the former site of the Stadium of Domitian. The Piazza was periodically flooded for festival pageants in this period, and the project of the fountain itself contains elements of evident allusions to the story of Noah in the Bible and to the Ark (Shepard 2012). The fountain consists of a basin from which stony crags in travertine rise to support a granite obelisk in the centre, which was taken from the Circus Maxentius, later named as Obeliscus Pamphylius (Kircher 1650). Reclining on this mountain-like base with internal cavities similar to grottos from which the waters originate are the monumental figures that symbolise the river gods, meant to represent the four continents known at the time (D’Onofrio 1957; Brandi 1972) (Fig. 1).

The German Jesuit Athanasius Kircher had the arduous task of translating the obelisk's hieroglyphic inscriptions (many years prior to the discovery of the Rosetta Stone) (Rowland 2001). He most likely played a prominent role in the iconographic project and in Bernini's project being chosen over that of Borromini (Shepard 2012). Each allegorical figure is surrounded by fauna and flora meant to help identify his respective continent. The Danube accompanied by a horse and a backdrop of citrons represents Europe, the Nile surrounded by a lion and palm tree represents Africa, the Ganges with a dragon and a few plants represent Asia, while the Rio della Plata with the armadillo and prickly pear represents the Americas. Similarly, the flowers and fruits of the cornucopias associated with the papal coat of arms are immediately recognisable symbols for the formal character and symbolic value associated with them (D'Onofrio 1957).

The fountain has been the subject of numerous historical and artistic studies, some of which have also touched upon aspects related to nature (Rowland 2001; D'Amelio and Marder 2011). Apart from the most obvious associations between flora and rivers, there has been no mention

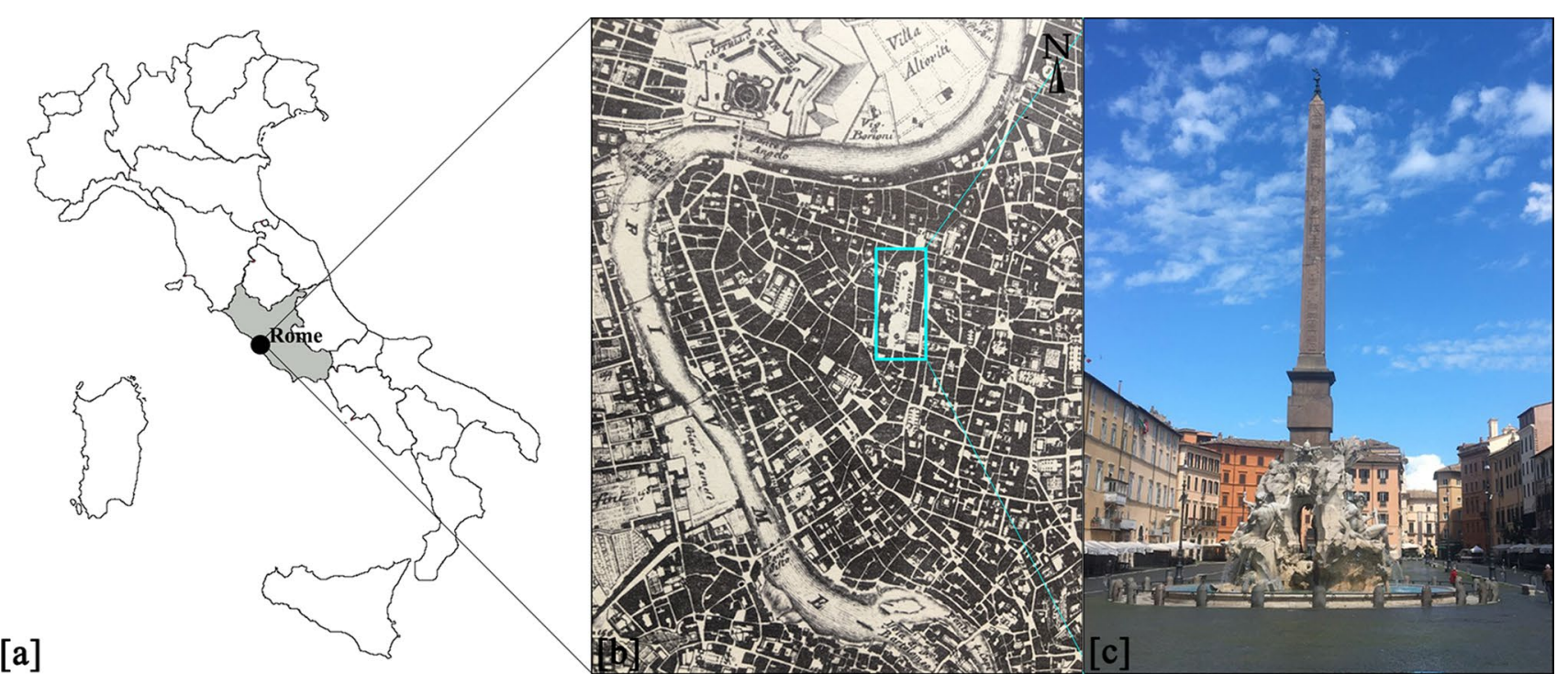

Fig. 1 a Location of Rome (Italy) where the Four Rivers Fountain is located; b Placement of the fountain in Navona square (corresponding to the Domitian stadium) in the G.B. Nolli map (1748 in Frutaz 1962); $\mathbf{c}$ the fountain with the obelisk (Photo by G. Caneva 2020) 
of the numerous other plant species used to represent rivers and hence the continents, nor a possible explanation that guided the artist's choice. Therefore, in this study, we intend to provide an interpretative analysis that identifies and defines them as a whole to better determine the common denominator that may have guided their selection. This analysis also aims to outline the iconographic selection made in the context of the purpose with which the plants were chosen.

\section{Methods}

The restoration of the fountain (Pandolfi 2012) made it possible to closely observe the details carved on the rocky base, facilitating the study of the morphological characters of the plants sculpted and their comparison with those found in several floristic texts (Bonnier 1911-1933; Bartolucci et al. 2019; Galasso et al. 2019; Pignatti 2019) as well as that in the photographic documentation collected. An iconographic study of the sculptures was associated with an analysis of the documentation available in the archives relating to the execution of the fountain, drawn up to keep track of the progress of the work and relative costs (Codex Corsinianum 167). The floristic elements resulting from this analysis were compared with the illustrations taken from the sixteenth century medical-botanical treatises, such as those of P. Andrea Matthioli (1565), Castore Durante (1585) and Ulisse Aldrovandi (Alessandrini and Ceregato 2007), and of the Linceo Federico Cesi (Pignatti and Cipriani 2010).

A dataset was, therefore, defined containing a list of the species that were identified, their updated nomenclature according to the Plant List (2013), their vernacular name, the part of the sculpted plant, along with the river god and/ or the papal coat of arms with which it is associated.

Reference was made to classical sources (Pliny and Dioscorides) and to the work of Cesare Ripa (1603) to interpret the associated symbolic values. An important reference was Levi D’Ancona (1977) who provided different interpretations according to the contexts and myths. Further sources have been found in the most recent literature (Kandeler and Ulrich 2009a, b, c, d, e, f, g, h, i, j; Farcas et al. 2015; Signorini and Zucchi 2018).

Finally, a comparison was made with the flora represented in the Trevi Fountain by Nicola Salvi in the late Baroque period (1732-1762). Even though the Trevi Fountain was created about a hundred years later, it appears to be somewhat inspired by this model for there are several similarities, such as the rocky areas that host the sculpted flora, and travertine, the stone with which different plants, trees and others were carved (Caneva and Dinelli 1991).

\section{Results}

The amount and distribution of the 34 species in total that were identified are shown in Table 1 . The interpretation of the associated symbolic values will be evaluated in the discussion, together with the other purposes of their portrayal. Some of them are cited with the common names in the administrative documents (Codex Corsinianum 167), whereas other are generically indicated as "flowers and fronds".

\subsection{The rivers on the eastern side}

\subsubsection{The Nile and Africa}

The main plant associated with the Nile, clearly evident in shape and size, is the date palm, Phoenix dactylifera L. (Palmae), as reported in the book-keeping accounts of the time (Codex Corsinianum 167: on the same boulder there is a palm tree, 39 palms high... scudi 270) (Fig. 2a). This paleo-subtropical species has occupied a large area that extends from Senegal to the Indus basin since prehistoric times, with particular abundance in the regions from the Euphrates to the Nile (Pignatti 2019). The accuracy with which the palm was sculpted is such that even Brandi (1972) 'does not at all exclude that Bernini showed how the rocks and palm were to be made'. In particular, the carved trunk which shows the marks of the leaf scars and the 'arching' fronds are very realistic. The absence of fruits (dates) is a 'missing' detail that could have several interpretations.

Less evident though still important are the many plants carved at the base of the palm tree next to the lion, as chronicled in the accounts (Codex Corsinianum 167, XIV: there are many plants next to the lion, where blue wheat is also portrayed with great attention and effort). Among these plants, there is one belonging to Poaceae, the only plant attributable to 'blue wheat', just under $2 \mathrm{~m}$ high, herbaceous in growth, with an erect stem and linear-lanceolate leaves. Although corn (Zea mays L.) was often referred to with the name Frumentum turcicum (Fuchs 1542) or Frumentum indicum (Matthioli 1565) in sixteenth century herbaria, it can be excluded that it is in fact maize. The scarce morphological affinity and the absence of a historical-geographical link with the Nile and Africa lead us to reject this hypothesis, identifying this species as millet (Panicum miliaceum L.) or more likely as sorghum (Sorghum bicolor). The characteristics portrayed are in fact somewhat unclear and the second proposal seem more probable due to the dense and erect panicles. There is no mention of the other herbaceous plants sculpted in the 
Table 1 Identification and distribution of the floristic elements carved on the Fountain of the Four Rivers (RM)

\begin{tabular}{|c|c|c|c|c|c|c|c|c|c|}
\hline \multicolumn{2}{|l|}{ Proposed identification } & \multirow[t]{2}{*}{ Carved part of the plant } & \multicolumn{4}{|c|}{ River context } & \multirow[t]{2}{*}{ Apical rock } & \multicolumn{2}{|c|}{ Coat of arms } \\
\hline Scientific name & Common name & & Nil & Gan & $\mathrm{RdP}$ & Dan & & North & South \\
\hline Phoenix dactylifera $\mathrm{L}$. & Date palm & Entire plant & $*$ & & & & & $*$ & \\
\hline $\begin{array}{l}\text { Panicum miliaceum L./Sorghum } \\
\text { bicolor (L.) Moench }\end{array}$ & Millet/sorghum & Culms, leaves and fruits & $*$ & & & & & & \\
\hline Papaver somniferum L. cf. & Opium poppy & Flowers, fruit and leaves & $*$ & & & & & & \\
\hline Verbascum sinuatum L. & Mullein & Basal leaves & $*$ & & & & & & \\
\hline Convolvulus sp. & Bindweed/morning glory & Branch with flowers & $*$ & & & & & & \\
\hline Artemisia sp. & Mugwort & Basal leaves & $*$ & & & & & & \\
\hline Salvinia cf. natans All. & Floating fern/watermoss & Leaves & & $*$ & & & & & \\
\hline Hepaticae cf. & Hepatica/liverleaf/liverwort & Pulvinus & & $*$ & & & & & \\
\hline Musci & moss & Pulvinus & & $*$ & & & & & \\
\hline Typha cf. latifolia $\mathrm{L}$. & Broadleaf cattail/bulrush & Leaves & & $*$ & & & & & \\
\hline Opuntia ficus-indica (L.) Mill. & Prickly pear/Barbary fig & Entire plant with fruit & & & $*$ & & & & \\
\hline Citrus medica $\mathrm{L}$. & Citron & Fruit & & & & $*$ & & & \\
\hline Campanulaceae/Convolvulaceae & Bellflower & Flowers & & & & $*$ & & & \\
\hline Malvacae & Mallows & Flowers & & & & $*$ & & & \\
\hline Laurus nobilis L. & Sweet bay & Leaves & & & & $*$ & & & \\
\hline $\begin{array}{l}\text { Arundo donax L. (Arundo plinii } \\
\text { Turra) }\end{array}$ & Giant reed/giant cane & Entire plant & & & & $*$ & & & \\
\hline Alcea cf. rosea/Althea officinalis $\mathrm{L}$. & Hollyhock & Flowers & & & & $*$ & & & \\
\hline Hibiscus syriacus $\mathrm{L}$. & Hibiscus & Flowers & & & & & * & & \\
\hline Verbascum thapsus L. & Great mullein & Basal tuft & & & & & $*$ & & \\
\hline Ranunculus scleratus L. & Celery-leaved buttercup & Flowers & & & & & $*$ & & \\
\hline Ceterach officinarum Willd. & Scale fern/rustyback fern & Leaves & & & & & $*$ & & \\
\hline Veronica cymbalaria Bodard & Glandular speedwell & Plant with flowers & & & & & $*$ & & \\
\hline Marchantia polymorpha $\mathrm{L}$. & Liverwort & Vegetative thallus & & & & & $*$ & & \\
\hline Paeonia sp. & Peony & Flowers and leaves & & & & & & $*$ & \\
\hline Lilium cf. & Lily & Flowers & & & & & & $*$ & \\
\hline Rosa $\times$ damascena Herrm. & Rose & Flowers & & & & & & * & \\
\hline Olea europaea $\mathrm{L}$. & Olive & Branch with fruits & & & & & & $*$ & $*$ \\
\hline Lilium/Iris & Lily/Iris & Flower & & & & & & $*$ & $*$ \\
\hline Triticum aestivum $\mathrm{L}$. & Common wheat & Ears & & & & & & $*$ & $*$ \\
\hline Pinus pinea $\mathrm{L}$. & Stone pine & Pine cone & & & & & & & $*$ \\
\hline Punica granatum $\mathrm{L}$. & Pomegranate & Fruit & & & & & & & $*$ \\
\hline Malus domestica Borkh. & Apple & Fruit & & & & & & & $*$ \\
\hline Cydonia oblonga Miller & Quince & Fruit & & & & & & & $*$ \\
\hline Vitis vinifera $\mathrm{L}$. & Grapevine & Leaves and fruit & & & & & & & $*$ \\
\hline
\end{tabular}

Nil Nile, Gan Gange, RdP Rio della Plata, Dan Danube, $N$ North, $S$ South

document of the time, but the carved details allow us to identify four types. The first plant, close to the lion, would seem to be a poppy, perhaps the opium poppy (Papaver cf. somniferum) due to the large tetramer flowers and the shape of the leaves, even if the absence of capsules makes the choice uncertain. Among the other plants, there is a "cluster" of bell-shaped flowers which seem to be placed in this manner for spatial and aesthetic effect, generically identifiable as bindweed (Convolvulus sp.). Only the leaves are carved of other plants, one is pinnatisect and laciniate, while the other ones are linear with a crenate-toothed margin, which could be attributed, respectively, to species of the genera Artemisia and Verbascum.

\subsubsection{The Ganges and Asia}

The rocky formation sculpted near the Ganges is devoid of plants and the bare rocks form a backdrop to the river god who is elegantly crowned by long ribbon-like leaves, slightly 


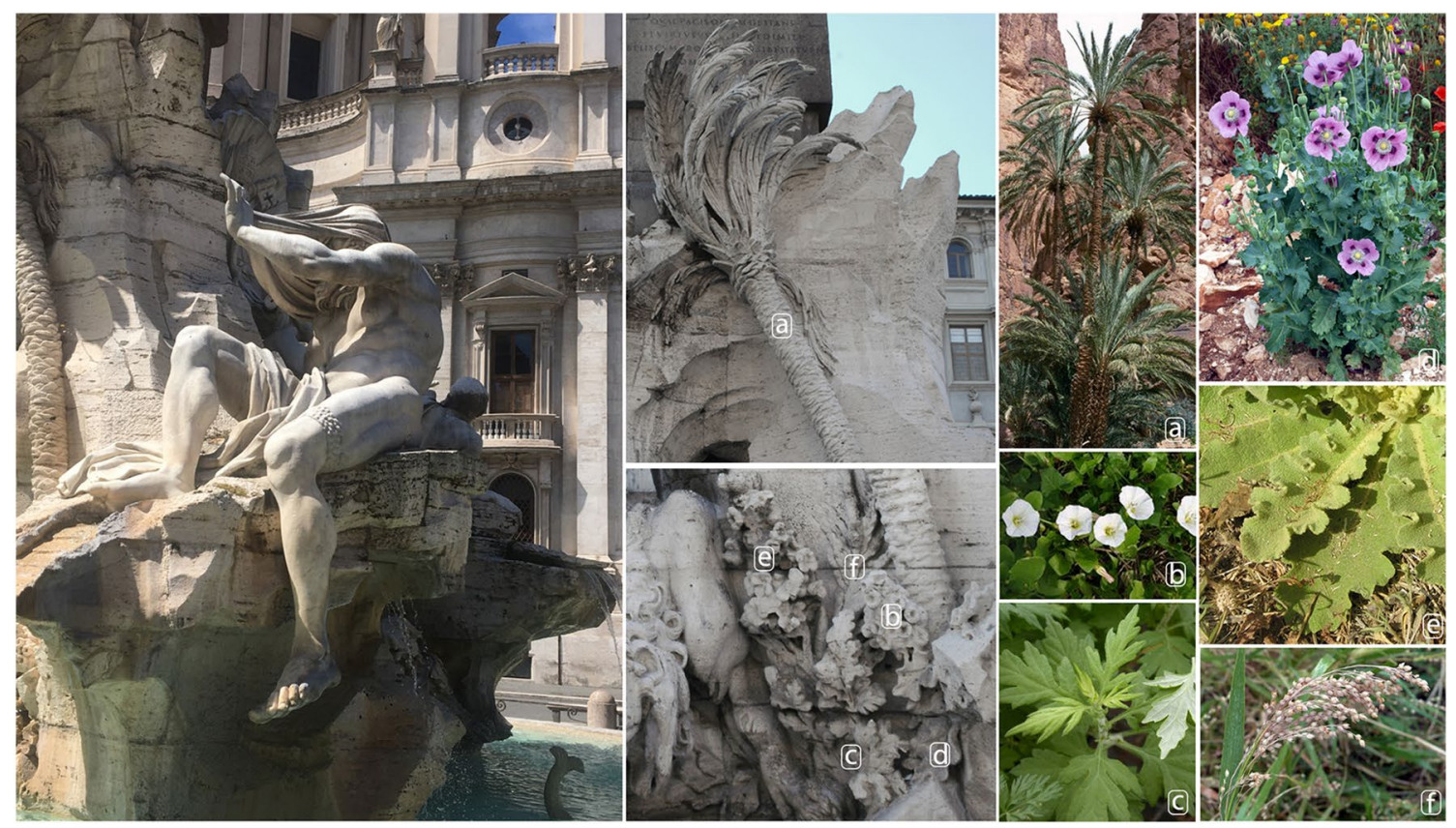

[a] Nile river: divinity, carved details and real plants
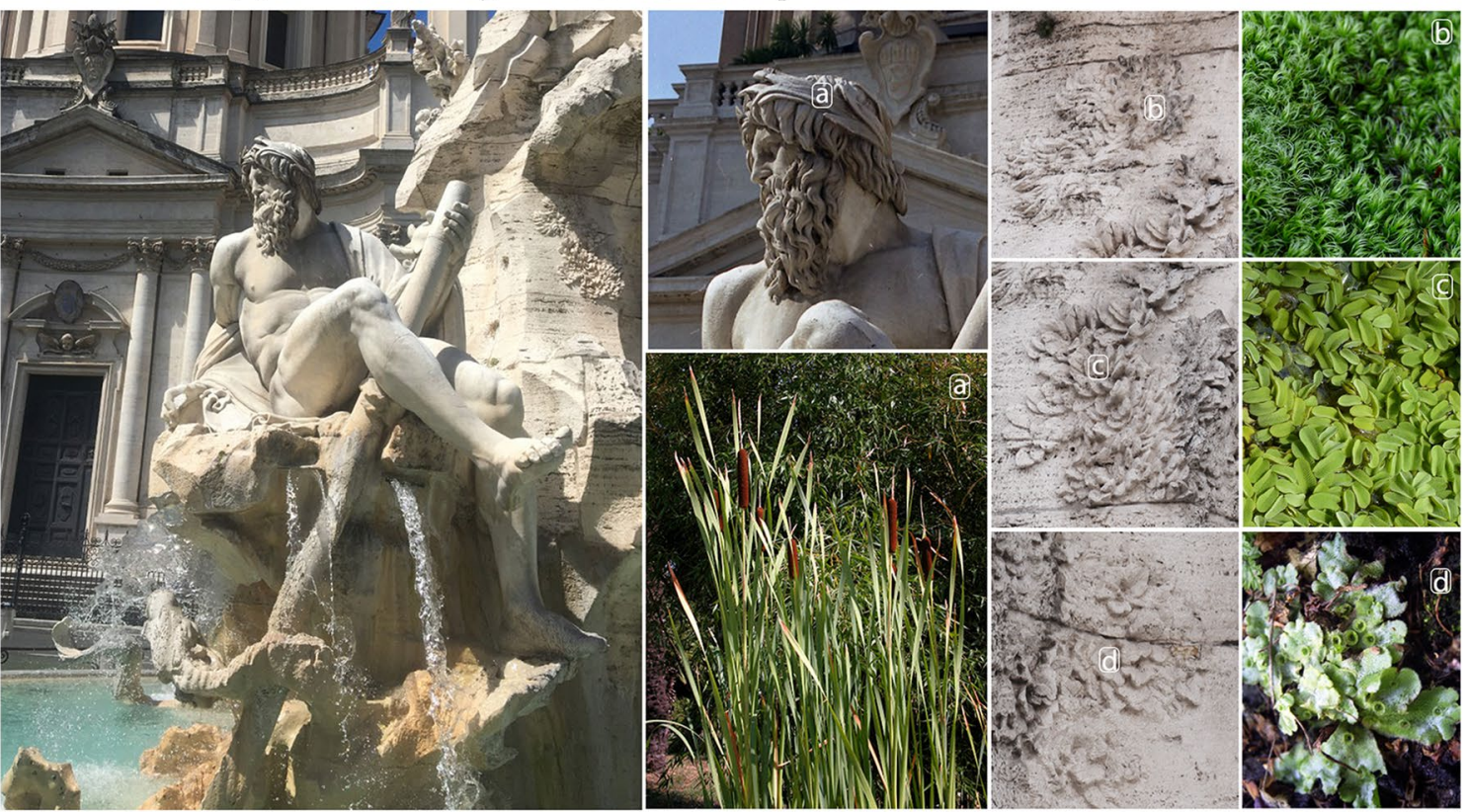

[b] Gange river: divinity, carved details and real plants

Fig. 2 Fountain scheme of Rivers on the Eastern side: a Plants associated with the Nile river: [a] Phoenix dactylifera L.; [b] Convolvulus sp.; [c] Artemisia sp.; [d] Papaver somniferum L.; [e] Verbascum sinuatum L.; [f] Panicum miliaceum L./Sorghum bicolor L.; b Plants

intertwined (Codex Corsinianum 167 VI: some low growing plants above the rock on the Ganges side) (Fig. 2b).

Only three sparse groups of 'low-growing' plants, vaguely hemispherical in shape, are carved on the right side of the rocks. Two of them seem to represent mosses and Hepaticae pulvini, respectively, located at the top and associated with the Gange river: [a] Typha latifolia L.; [b] Moss; [c] Salvinia natans (L.) All.; [d] Marchantia polymorpha L. (Photo of the fountain by G. Caneva 2020), and of plants mainly by dryades http://dryades.units.it/floritaly/)

the bottom; while in the third group, it is possible to discern the characteristic elliptical-ovate leaves of the small aquatic fern Salvinia cf. natans (floating fern) which grows in slow-flowing waters in much of the Eurasian region. The linear and flexuous leaves that form the crown on the river god's head, albeit partially reconstructed, have 
a rounded shape reminiscent of the leaves of Typha cf. latifolia (broadleaf cattail), a very common river plant, present in swamps, ponds and ditches, with a wide geographical distribution.

\subsection{The rivers of the Western side}

\subsubsection{Rio della Plata and the Americas}

The prickly pear (Opuntia ficus-indica L.), (Codex Corsinianum 167, VII: a prickly pear plant from the Rio della Plata), on the NW section of the fountain, together with the "tatù" that is, the armadillo that comes out of the rock on the north side, the large snake which could be interpreted as an anaconda as well as the stack of coins on the rocks are the symbols chosen to represent the "New World" (Fig. 3a).

Here, the species is portrayed quite realistically both in terms of size (about $2 \mathrm{~m}$ ) and accuracy with a precise depiction of its ellipsoidal cladodes (commonly known as "pads") with well-marked rhomboid veins and ovoid-shaped edible fruits. The scant knowledge of the flora of the still unexplored New World is characterised by the portrayal of "astounding" animals which explains the reduced number of florae sculpted here.
Fig. 3 Fountain scheme of Rivers on the Western side: a Plants and animals associated with Rio della Plata rivers: [a] Opuntia ficus-indica (L.) Mill.; [b] Dasypus novemcinctus L. 1757; b Plants associated with the Danube river: [a] Viburnum tinus L.; [b] Laurus nobilis L.; [c] Campanulaceae/Convolvulacee; [d] Citrus medica L.; [e] Acea roseal Althaea officinalis. (Photo of the fountain by G. Caneva, 2020), and of plants mainly by dryades http://dryad es.units.it/floritaly/)
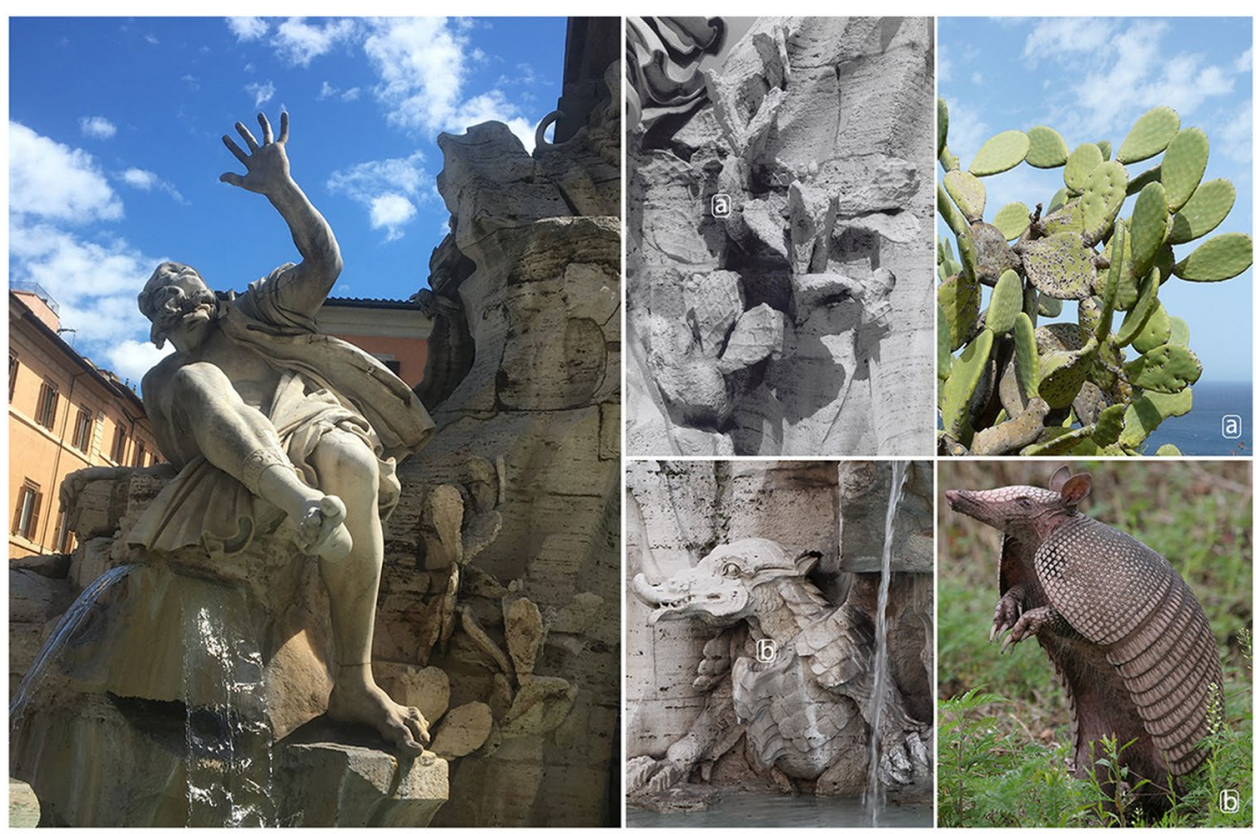

[a] Rio della Plata river: divinity, carved details and real plants

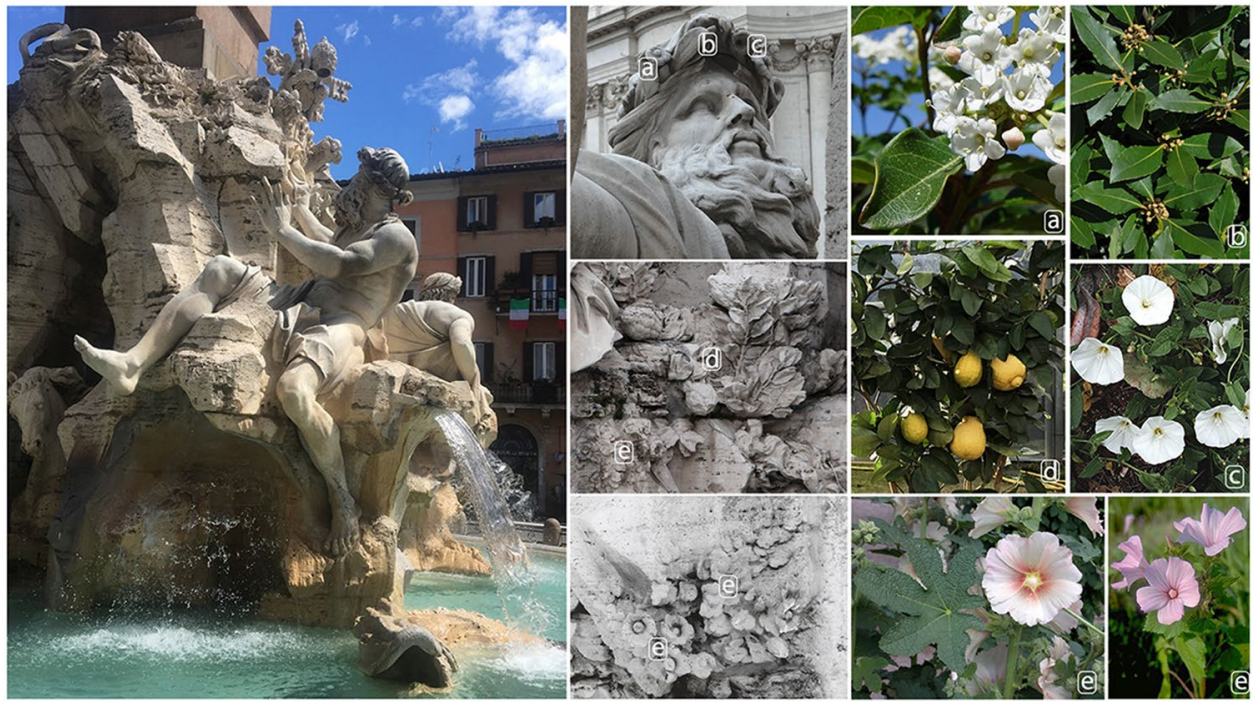

[b] Danube river: divinity, carved details and real plants 


\subsubsection{The Danube and Europe}

A backdrop of citron branches (Citrus medica L.) is clearly recognisable on the rocky crags to the right of the Danube, (Codex Corsinianum 167, XII: a backdrop of citron branches; which have its leaves and fruits all carved in relief) (Fig. 3b). They can be identified by the characteristic oblong shape of the fruits, prominent at the base and apex, with a furrowed surface, with shapes and proportions that reflect the ones in nature with great precision. There are some flowers next to the citrons that were not mentioned in the document of the period which recall several species of Malvaceae, owing to the shape of the corolla and the large central stylus on which the stamens grow. Most likely, it is a plant of the genus Alcea (hollyhock) and probably A. rosea. The figure that represents the Danube is wearing a crown of leaves (some are of laurel, Laurus nobilis, while others are not clearly defined) with at least three types of flowers that are of vague taxonomic identification, which are, therefore, only proposed at the family or genus level (Campanulaceae/ Convolvulaceae, Malvaceae and probably Viburnum).
Last of all, inside the grotto, at the base of the rocky formation, there are still some traces of the sculpted reed beds, (Codex Corsinianum 167, XI: inside the grotto where the horse comes out, a handful of reeds and its reed-like fronds can be seen). The morphological characteristics available make it difficult to distinguish whether they could represent Arundo donax L., a cosmopolitan and spontaneous plant found along watercourses or A. plinii Turra, a species that is more typical of our geographical contexts.

\subsection{The apical rocks and the papal coat of arms}

We find rich herbaceous vegetation at the top of the rocky crags in the area dedicated to the Danube (Codex Corsinianum 167, III: above the outer edge of the rock on the Danube side there are many flowers and fronds) (Fig. 4). The dense tufts of leaves on the rocks facing west, strictly adjacent to the snake moving towards the apex, are identifiable as those of mullein (Verbascum cf. thapsus). Among these leaves, it seems possible to identify a plant of Malvaceae, probably hollyhock (Alcea $\mathrm{cf}$. rosea) and a flower of more

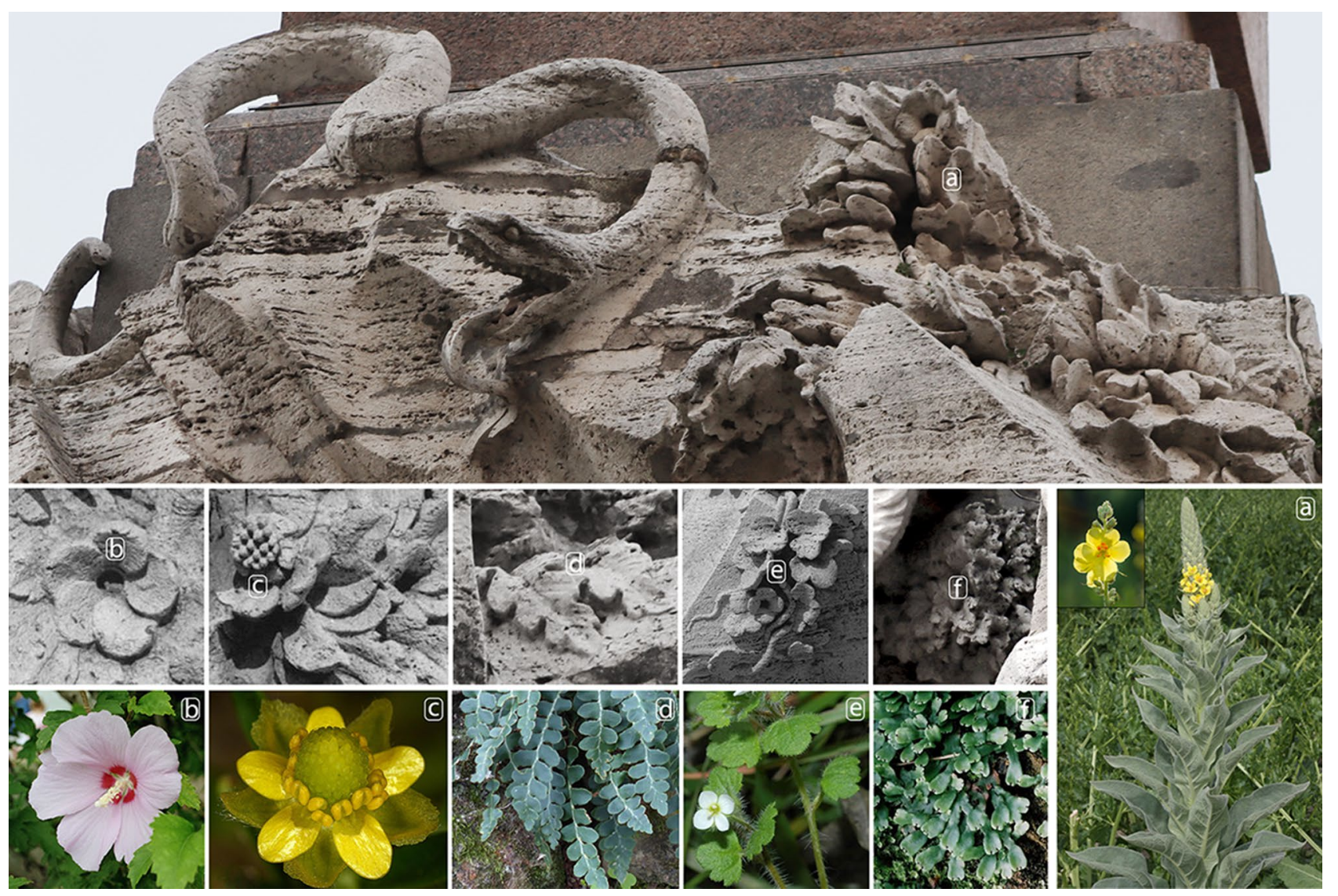

Fig. 4 Plants at the top of the rocky crags, with the snake hindered by the mullein: [a] Verbascum thapsus L.; [b] Hibiscus syriacus L.; [c] Ranunculus sceleratus L. [d] Ceterach officinarum Willd.; [e] Veron- ica cymbalaria Bodard; [f] Marchantia $\mathrm{cf}$. (Hepaticae). (Photo of the fountain by G. Caneva, 2020), and of plants mainly by dryades http:// dryades.units.it/floritaly/) 
dubious interpretation, perhaps attributable to a Ranunculaceae species (Ranunculus sceleratus $\mathrm{cf}$.). Rupestrian species such as Ceterach officinarum emerge from the rock, identifiable by its characteristic leaves, and another reptant plant with tetramerous flowers, identifiable as Veronica cymbalaria. Finally, behind the southern coat of arms, there are pulvinus of hygrophilous rupestrian species probably identifiable as liverwort (see Riccia).

\subsubsection{The North}

The papal coat of arms on the north side (Fig. 5a) contains three lilies (Lilium) in the recurring heraldic transposition with the Iris, as well as a stylised rose (Rosa sp.) and two bunches of wheat ears (Triticum aestivum L.) on each side, crowned by palm fronds (Phoenix dactlylifera). There is a dove with an olive branch in its beak placed in the middle of the coat of arms.

Some peonies are present on the inner wall of the grotto, and are related to the following context-(Codex Corsinianum 167, V: To have carved some peonies with its fronds in the boulder which are positioned on the side of the Rio della Platta, all stand out in good numbers and with much diligence, is estimated at a cost of scudi. 30). In the European Caucasus region, the most important species are Paeonia officinalis L. and P. mascula (L.) Miller which
Fig. 5 Plants associated with the papal coats of arms: a Northern side: [a] Rosa $\times$ damascena Herrm.; [b] Phoenix dactylifera $\mathrm{L} . ;$ [c] Triticum aestivum L.; [d] Lilium candidum L.; [e] Paeonia sp.; [f] Iris $\times$ germanica L.; [g] Olea europaea L. b Southern side: [a] Vitis vinifera L.; [b] Iris $\times$ germanica L.; [c] Cydonia oblonga Mill.; [d] Pinus pinea L.; [e] Punica granatum L.; [f] Triticum aestivum L.; [g] Malus domestica Borkh.; [h] Olea europaea L. (Photo of the fountain by G. Caneva, 2020), and of plants mainly by dryades http://dryades.units.it/ floritaly/)
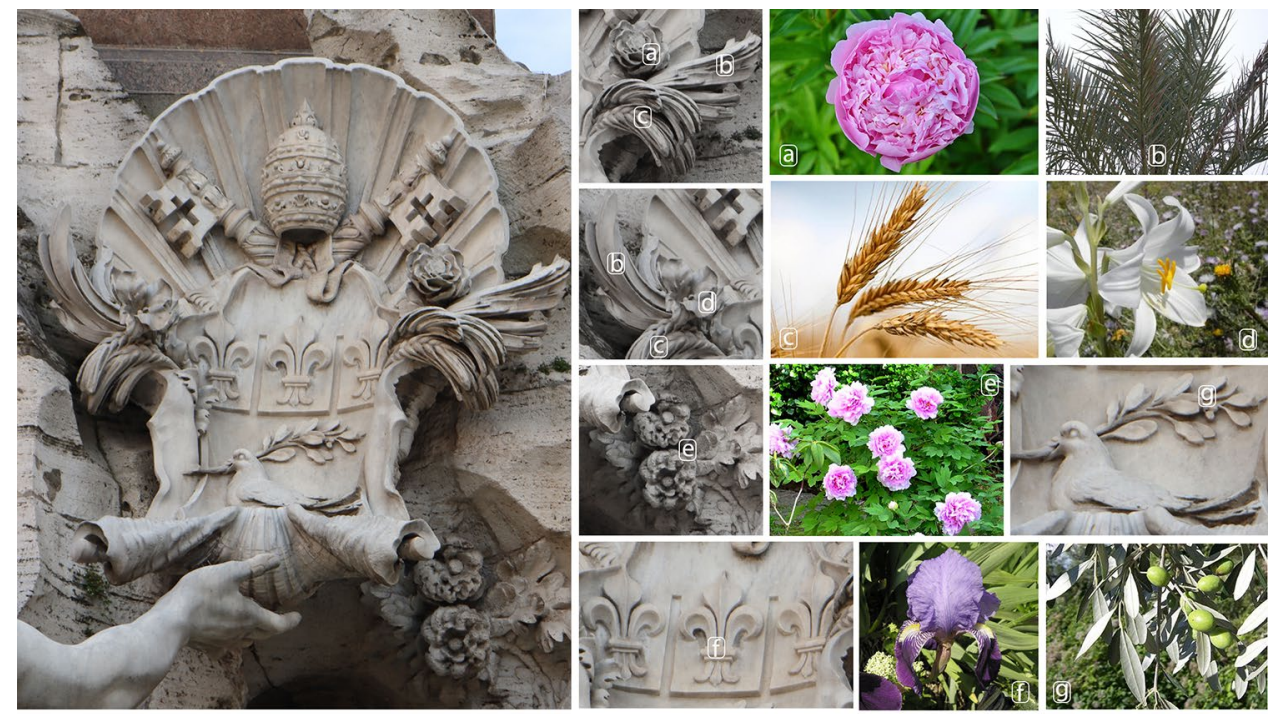

[a] North Papal coat: coat, carved details and depicted plants

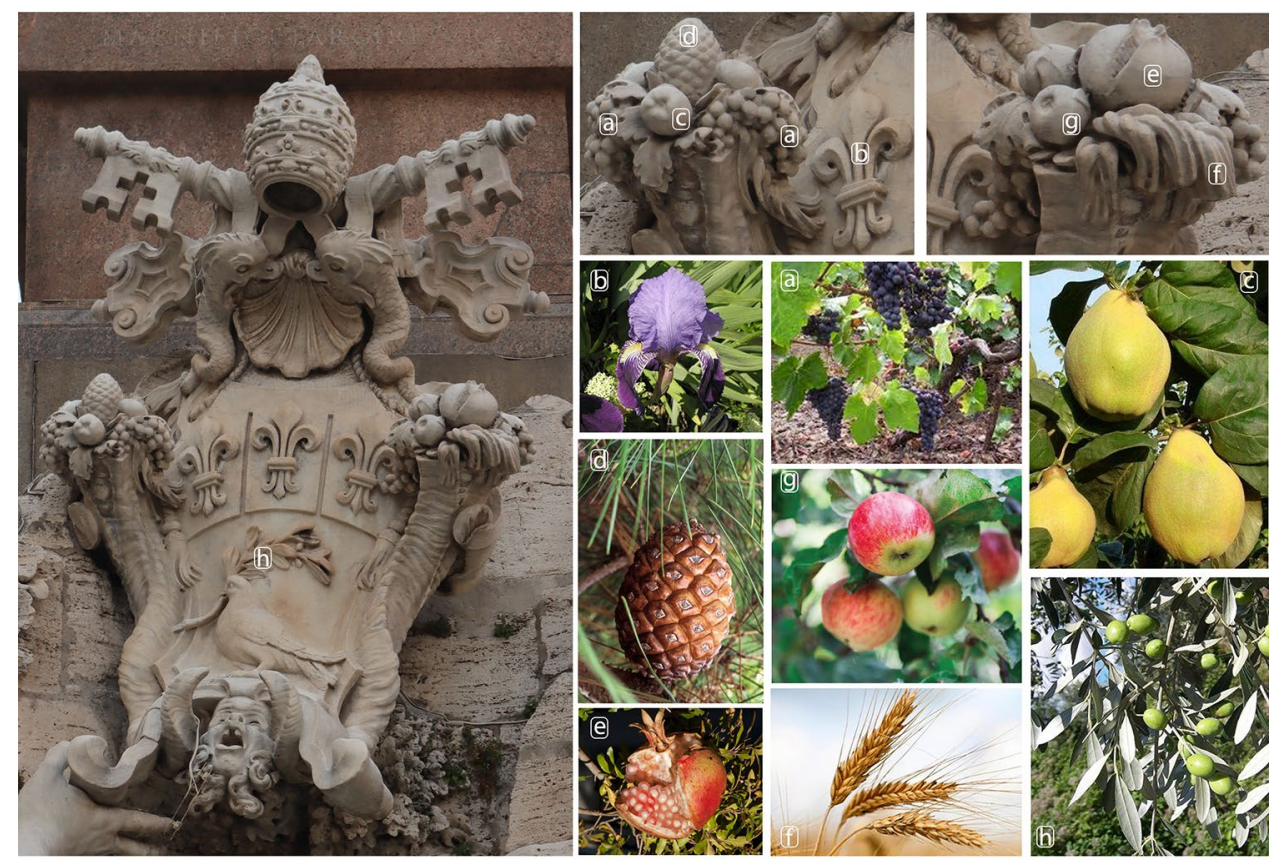

[b] SouthPapal coat: coat, carved details and depicted plants 
grow spontaneously in wooded areas and clearings. Both are characterised by showy flowers compatible with those sculpted here, even if the absence of chromatic characteristics or sculptural details does not allow a more precise identification. The morphometric data are superior to those of spontaneous peonies and more similar to those of cultivated peonies.

\subsubsection{The South}

The coat of arms of the southern side is characterised by two opposing cornucopias (Fig. 5b) which contain apples (Malus domestica Borkh.), quinces (Cydonia oblonga Miller), clusters of grape (Vitis vinifera L.) and ears of wheat (Triticum aestivum), while at the top of the coat of arms, we identified a pine cone (Pinus pinea L.) and a pomegranate (Punica granatum $\mathrm{L}$.) together with traces of leaves. There are also other plant elements on the rocky formation below this coat of arms (Codex Corsinianum 167, IV: To have carved some flowers and fronds mostly done very great diligence and effort is estimated at scudi 25). There is a dove with an olive branch in its beak, similar to the coat of arms on the northern side.

\section{Discussion}

Not only did the religious and political intents influence the design of the fountain, but the festive ephemera of the baroque period also played a part (Fagiolo 1997). According to Shepard (2012), the Fountain contains many levels of meanings which have resulted in several interpretations.

It has been said that the spectacular nature of the fountain was due to the artist's ability to blend together elements of architecture and sculpture, thus expressing a sense of movement in every sculpted detail whether human, animal or vegetable, making it the scenographic fulcrum of the entire square, capable of arousing a sense wonder and discovery in spectators who, moving around the fountain discovered hidden details (Fagiolo and Fagiolo 1967). While agreeing with the aforesaid authors that "Bernini is too rational to introduce imaginary objects or monstrous chimeras: the starting point is always the simple and immediate reality" (Fagiolo and Fagiolo 1967), this rationalism is placed in a historical period that still uses the symbolic value of perceptible reality as a form of communication.

Moreover, the presence of Kircher should not be underestimated, as he fully supported Bernini's project, and not only did he play a role only in interpreting the hieroglyphic inscriptions but he also advocated the idea of creating a fountain to reveal both the "the mysteries of divinity and Nature's law" (Rowland 2001). Indeed, the pairing of the obelisk and the hydrophylacium (water reserve) in the
Kircher's Mundus Subterraneus (1678) embodied the principal idea of the Fountain from its first traceable beginnings, The Bernini fountain, gushing water from cavernous overhangs and through hidden channels, begins with the idea that its stony crags are the source from which the waters of the whole world spring forth (Rowland 2001). This idea then evidently evolved, placing the emphasis on religious ideas aimed at highlighting the central role of the Church and of Pope Pamphilj in the world. Bernini would then use Kircher's ideas, together with the ephemeral sources to create the final design of the fountain which would also represent the Church's secular authority in the world (Shepard 2012).

The obelisk and the symbolism associated with it are also of great importance. First of all, the fountain with its prominent obelisk in the middle of the piazza recalls the ancient circuses and stadia of Roman emperors emphasising their dominant role in the world. In particular, the "innocent dove" with an olive branch and lilies refers to the Pamphilj coat of arms and to the Pope himself, as well as being a biblical reference to the Great Flood and symbol of the Holy Spirit. The Egyptian monsters that threaten the innocent dove which is placed atop the obelisk with the victory of the Roman Church could refer to heretics, Protestants and political opponents (Shepard 2012).

Thus, in interpreting the distribution pattern of the rivers, there seems to be a symbolic logic of the distribution of the primeval waters of Eden in the four main directions, with reference to what is found in Genesis (2:8-10 "A river watering the garden flowed from Eden; from there it was separated into four headwaters."). Apart from the obvious allegorical association of the rivers remarked upon by many authors (D'Amelio and Marder 2011; Rowland 2001; Shepard 2012), little attention has been given to the sequence and positioning of the rivers themselves. This has a different meaning from the straightforward geographical location with respect to Rome (e.g. apart from the Ganges being to the SE, the Nile is to the NE, the Rio della Plata to the NW; the Danube to the SW). The placement of the papal coats of armsone to the north and the other to the south-constitutes the cardinal axis of the symbolic system of the narrative, that gives them maximum visibility, reconnecting them to the cardinal system of the Earth's orbit. This axis divides the two principal delineated contexts that provide "orientation", in the literal sense of the word, with the East, represented by the Nile and the Ganges (Africa and Asia) and the West by the Danube and Rio della Plata (Europe and the New World).

This particular positioning of the rivers can, however, be explained only if one imagines a double reversal (first from north to south and then an east-west inversion) and then a further rotation (in that case the Danube and hence, Europe would regain its normal position to the north, the Nile and Africa to the south, the Rio della Plata and the Americas to the west and the Ganges and Asia to the east) (Fig. 6). 

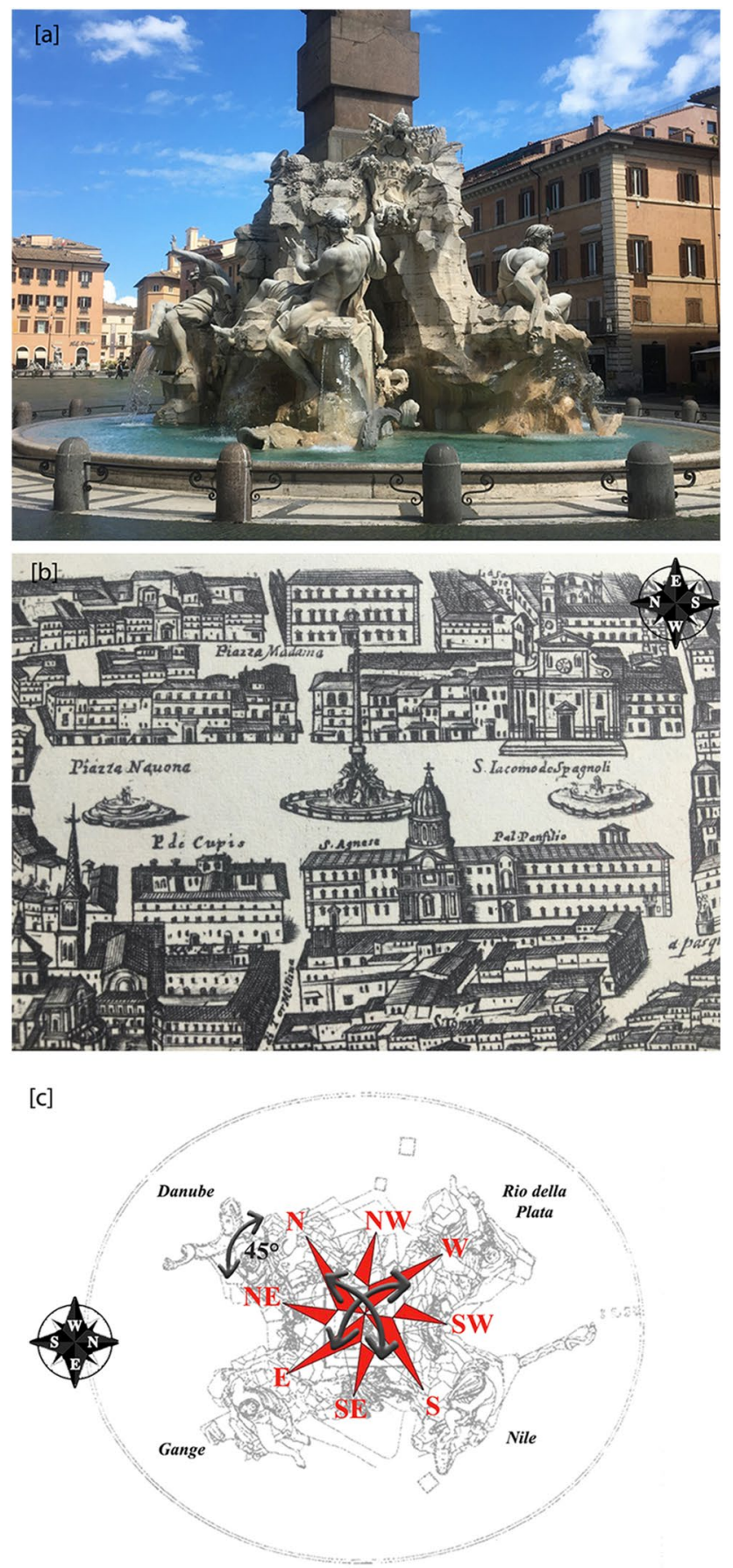

Fig. 6 a The Four Rivers Fountain (Photo by G. Caneva, 2020); b Navona Square with the Fountain in the G. Vasi map (1781, in Frutaz 1962) c Reconstruction of rotation schemes of the fountain in relation to the rivers, which derives if the rivers had been portrayed by observing them from a reversed, mirror image and at the same time rotated by a further 45 degrees (see on the left the true orientation and on the right the modifications which has been carried out on the fountain trough double overturning)
It is as if the rivers had been portrayed by observing them from a reversed, mirror image and at the same time rotated by a further 45 degrees. This gives a sense of dynamism and determines a change of perspective which has an evident symbolic yet cryptic meaning. This rotation should not surprise us, because everything is "tortuous" in the fountain, from the busts of the river gods, to the papal coats of arms, to the rocks. At any rate, convoluted movement and the denial of perfect symmetry are typical elements of the Baroque (Fagiolo and Fagiolo 1967).

The symbolic message is both evident though cryptic, and probably intentionally intelligible only to those of science and religion, in line with the image of Harpocrate "who appears portrayed in the frontispiece of the Kircherian volume Obeliscus Pamphilianus", with his finger to his lips to signify "if you understand, keep your silence" (D’Amelio and Marder 2011).

We can also suppose the influence of further "specialists" in Roman intellectual circles who might have guided the artist in his choices. Considering the roman scientific context at that time, both the botanists Pietro Castelli and Tobia Aldini could have a relevant influence. Castelli was born in Rome and later became professor at La Sapienza and the director of the "Orto Vaticano", before his moving in Messina in 1635. Tobia Aldini came from Cesena becoming the curator of the Farnese Gardens on the Palatine Hill, and he remained in Rome until his death in 1662, having a possible direct influence with Bernini's works. Both probably contributed to the famous contribution to the rare plants of the Hortus Farnesianus (Castelli and Aldini, 1625), even if some scholars believe that, in reality, the name in the frontispiece is a pseudonymous of the first one. Moreover, in that historical period, the importance and influence of botanical studies were very relevant, when also considering the works of the Neapolitan Lincei Giambattista della Porta and Fabio Colonna, and the comments to the Rerum medicarum Novae Hispaniae Thesaurus..., that the Lincei published at first in 1628, and later in 1648.

In this context, the flora was certainly selected not only for its naturalistic value and scenographic verity but also to help convey a symbolic message.

If one simply focuses on biodiversity, we can see that as a whole, a total of about thirty flora species were sculpted on the stony crags and on the coats of arms (if one also considers those in the heraldic contexts) which is not a small number in this sculptural context. In fact, in the Trevi Fountain, about 20 species have been identified over a much greater surface area, even if in this case, the heraldic ones were not considered (Caneva and Dinelli 1991).

Apart from the number of sculpted species present on the fountain, it is the meaning that is important. The Fountain of the Four Rivers in the Piazza Navona was the direct archetype of the Trevi Fountain (Cooke 1956), but probably the 
historical and cultural change that was taking place at the time lessened the dominance of symbolic elements evident in the model. In the Trevi Fountain, most of the species are characteristic of rock, ruderal and aquatic habitats, while only the oak branch (Quercus sp.), laurel (Laurus nobilis L.) and acanthus fronds (Acanthus mollis L.) have a symbolic or celebratory purpose. Moreover, all the species are indigenous, with the exception of colocasia (Colocasia antiquorum Schott), which has long been cultivated for food and ornamental purposes (Caneva and Dinelli 1991).

The reason behind the choice of plants in the Four Rivers Fountain seems to combine realism and symbolism as the selection appears congruous with the identification of the geographic environments that they to contribute to represent, but at the same time, it is equally evident that there is also a symbolic intent for many of these plants.

The following section provides an analysis of the meanings of environmental contextualisation and the symbolic reference.

\subsection{The rivers on the Eastern side}

\subsubsection{The Nile: life and fertility}

The presence of the date palm which represents a sort of "tree of life" for Middle Eastern and North African populations is the most emblematic element of this context. The plant that "must dip its foot in the water and its head in the sky" (Figuier 1989) was considered immortal, just like the phoenix, in that it is capable of regenerating itself thanks to the new offshoots that emerge at the base of the plant crown (Kumbaric et al. 2013). Hence, it is the emblem of inexhaustible fertility and the symbol of victory (Levi D'Ancona 1977).

Kircher himself in his Obeliscus Pamphilius (1650) provides an interpretation of the lion emerging from a dark cave as symbolising learning and the Egyptian god Mophta, where the lion also represents the rainy season of the Nile, as the Sun enters into the Leo constellation. The palm symbolises the fertility of the Nile Valley owing to the annual floods (Simonetta et al. 2003). Here, the animals have an evident symbolic meaning. Kircher identifies the horse, which appears opposite the lion, with Typhon, the enemy of Osiris, and further equates Typhon with Seth, the Egyptian god of the dry desert wind who opposes the annual flood (Shepard 2012).

Cereals are also certainly associated with the idea of fertility - barley, wheat and millet—because in the culture of Mediterranean and Near Eastern populations, they represent the main symbol of the earth's fertility. The association with the Nile, the primary source of life and prosperity for the peoples of Egypt would have been a useful element in making this message even more explicit. In addition to this, the appellation of blue (with reference to the cereal) could be to reinforce the connection with the Nile, which the ancient Egyptians referred to as "blue". The poppy is appropriately associated with the Nile, as it is linked to cereals in ancient agriculture and, therefore, alludes to the idea of fertility. Its seeds were used for nutritional and medicinal purposes as was the latex for pain relief (Fabbri 2017).

Last of all, the other minor species as a whole (bindweed, mugwort and mullein) would have contributed to represent a natural and luxuriant habitat, congruous to the idea of the fertility of the Nile, though it cannot be excluded that they too may have a symbolic meaning. Mugwort is known for its medicinal and curative properties (Matthioli 1565), whereas mullein is regarded as a "bearer of light", so much so that it often appears in the paintings of Caravaggio (Pavesi 2010; Di Vito 2011). Bindweed could symbolise various elements which may at times be contradictory without a correct contextualisation.

\subsubsection{The "bare" Ganges}

Insomuch as "bare", the Ganges is associated with only a small number 'herbettes' or low growing vegetation (mosses, hepaticas, floating ferns, etc.) principally utilised to animate the stony crags of the fountain making it more similar to natural, rocky and river environments, such as Salvinia, albeit typical of slow flowing waters and the small sedges and bryophytes typical of the wetlands.

The linear and flexuous leaves of the crown that surrounds the head of the 'bare' Ganges do not seem to refer to individual segments of the pinnate leaves of a date palm as defined by Cesare Ripa (1603): the River Ganges of rigid aspect with a crown of palm on his head. The portrayal of broadleaf cattail or bulrush, a typical aquatic species is, therefore, quite pertinent in characterising a slow-flowing river as if to accentuate the idea of the easy navigability of the river, already expressed by the oar embraced by the divinity.

\subsection{Rivers of the Western side}

\subsubsection{Rio della Plata: the mysterious "New Indies"}

It seems likely that the presence of Kircher contributed to the choice of the rivers of the West, namely Rio della Plata, rather than the Mississipi, the "Father of the Waters" for Native Americans, and then the Danube, thus focusing the attention to two specific new areas of the Christian world, namely the territories evangelised by the Jesuits (D'Amelio and Marder 2011). While North America was considered inhospitable and sterile, South America was associated with wealth, as evidenced by the coins depicted near god symbolising the river which in Spanish means "Silver River" (which 
today is on the border between Argentina and Uruguay). The scarce knowledge of the flora of still unexplored New World also explains why the Amazon River was not chosen and also accounts for the modest number of plants sculpted here and a characterisation of that part of the world described mainly by the presence "astounding" animals. At the time, certainly very little was known of the "Americas" or "New Indies", and the lack of knowledge of these lands justifies the fact that the monumental figure of the Rio della Plata has somatic features which resemble more those of Africa rather than the Americas (San Juan 2012).

The choice of the prickly pear, originally from the tropical and boreal Americas, was certainly an emblematic element. Although today it is widely naturalised in Mediterranean environments, in the seventeenth century, it was evidently still recognised as an exotic plant from the New Indies. It should be remembered that the species, according to some authors, was imported into Europe with Columbus, but it is much more likely to have been introduced by the Spanish around 1520 (Donkin 1977). Its introduction in Italy dates back to 1560 and the first descriptions of this species are from Matthioli (1565) and Hernandez (1648). As an animal symbol, the armadillo of the Museum of Athanasius Kircher was probably the model and its portrayal should be interpreted as the "symbol and emblem" of the century of the surprising and fantastic (Capanna 2009).

\subsubsection{The Danube: the somatic and medicinal elements}

Similarly, the choice of the Danube was not as obvious as it might seem today in that it is the largest river in Europe. Bernini's preference over the Tiber is justified considering the Pope's intent to internationalise the Church and to utilise it to promote the jubilee in that part of Europe which was still not very evangelised (Christian 1986).

The choice of citron clearly has a symbolic value, because unlike the other plants chosen to refer to the rivers, it has no ecological relevance to the river. This citron, cultivated in China since ancient times, was introduced to the West by the Jews, and it has retained the idea of being a salvific element owing to its historical references and medicinal use. The Jews were familiar with this plant during their captivity in Babylon which ended with the expeditions of Alexander the Great to the East (327 BC), and from there, they brought it back to Palestine. It is highly esteemed by the Jews and is used to represent the heart in the Feast of Tabernacles ceremonies held mid-October to celebrate the end of the harvest season (Coggiatti 1986). We know that even in Christianity, the citron has retained a great augural meaning. This is probably due to the fact that it is evergreen and blooms even, while the former season's fruits are still on the tree. Its flowers are quite big and fragrant, and hence, these qualities of the etrog are some of the reasons why it came to symbolise an endless spring in Christianity (Ben-Sasson 2012). As far back as ancient times, both Theophrastus and Dioscorides described its use for medicinal purposes, which continued into the Renaissance up to the modern era (Matthioli 1565).

The plants inserted in this context would strengthen the connection of the Danube with the idea of an abundant and salvific nature. Not surprisingly, the crown of Campanulaceae/Convolvulacee, Malvaceae, laurel and other flowers which surround the river god's head expresses the idea of a lush nature, hence correlated to the waters of the largest European river and, therefore, to Europe itself.

\subsection{Apical rocks and papal coats of arms}

When analysing the group of herbaceous plants located at the top of the rocky crags, the portrayal of mullein tufts hindering the snake that has reached the tip is of particular iconographic interest. As already observed with regard to the Nile, a small nucleus of $V$. sinuatum was identified with its symbolic value as a "light bearer", as in general any Verbascum species (Pavesi 2010; Di Vito 2011), and here the positioning of basal tufts seems to have an even stronger meaning. The "evil" represented by the snake is opposed by the salvific value of this plant which forms an unmistakable barrier.

An ornamental as well as salvific meaning can also be attributed to A. rosea, known for its large semi-double or double flowers in a great variety of colours and for its medicinal use in the preparation of soothing remedies. If Althaea officinalis, also called marshmallow (Durante 1585) which is very similar to Alcea rosea, had been portrayed, the medicinal use would be equally evident.

Instead, Ranunculus sceleratus at the top, with liverwort at the bottom, and the Veronica cymbalaria were most likely chosen probably for naturalistic purposes, as they are representative of the aquatic, wetland and rupestrian habitats, respectively.

Their position is also in connection with the Danube river and the idea of a lush and salvific nature would be reinforced. Not surprisingly, the god representing this river has a crown of flowers and laurel on its head, which symbolise a luxuriant and salvific nature, further emphasised by Alcea/ Althea species having probably a medical value. These characteristics are then associated with the waters of the largest European river and therefore with Europe itself.

Finally, the yellow pond lily and the reeds portrayed are probably for naturalistic purposes, as well as to describe the aquatic habitat, along with the veronica which symbolises the rupicolous one. 


\subsection{The papal coats of arms}

\subsubsection{The North with the most noble and sacred flowers}

Symbols clearly associated with Pope Pamphilj appear on the papal coat of arms of the north side: the lily/iris is a symbol of purity and divinity, in reference to Juno, but according to some, it could also refer to peace and unity amongst Christian rulers as well as be a symbol of the mythical Golden Age (Preimesberger 1974). The rose is well known as a symbol of love and grace par excellence, with reference to Venus, as is the olive branch brought by the dove, representing peace. In this complex interpretation of the symbolic allegory, the Pamphilj coat of arms which contains all three symbols of Juno (lily), Venus (rose), and Minerva (olive), represents the end to war (the Trojan War that disunited the three goddesses) and the beginning of a peaceful era uniting three disparate entities into one (Preimesberger 1974). The ears of wheat are a symbol of bread and, hence, the body of Christ in Christianity (Levi D’Ancona 1977).

In addition, the peonies present on the inside of the grotto seem to pay homage to the splendour of the papacy not only because they are visually close to the papal coat of arms but principally because they represent 'noble' flowers. We know that at the beginning of the seventeenth century, double and single peonies were cultivated in the first botanical garden in Oxford in 1621 (Parkinson 1629; Harding 1993). However, it is difficult to understand whether they represent the opulent Asian peony which were only possessed by the imperial family and mandarins in ancient China and Japan (Koehn 1952; Fărcaş et al. 2015).

\subsubsection{The South}

The two opposing cornucopias are classic elements that evoke prosperity and wealth, and Greco-Roman iconography appears to be respected here also in lieu of the selection of fruit species (Caneva et al. 2019). Apart from apples, grapevines and wheat, for which there are numerous wellknown references also from a religious point of view (Levi D' Ancona 1977), it seems useful to observe that both the large pinecone and the large pomegranate are homologous elements from Ancient Roman times to indicate prosperity. However, the latter may also have been chosen for the additional meaning attributed to it, namely the unifying nature of the Church, which brings together a multitude of the faithful (Levi D'Ancona 1977). Finally, the olive branches are a symbol of peace and strongly connected with Pope Innocent X's family name "Pan philia" (all-loving) (Preimesberger 1974).

\section{Conclusions}

The wide variety of floristic species carved on the rocky formations and on the papal coats of arms of this monumental fountain has not only a decorative function. The selection and distribution of the carved plants are evidently associated with the quadrants of the fountain where they were positioned, which goes beyond the simple geographical combination with the four rivers. In fact, the different plants used are almost always descriptive of the environment and of the 'continent' that each river god represents, but they also have a very pertinent symbolic connections which should not escape the attention of a modern-day observer. Finally, the symbols of nobility, purity and prosperity are associated with the papal coats of arms, as an evident homage to the Papacy and Christianity.

The analysis of these naturalistic elements gives support in understanding the message behind their representation. Further studies in such direction are then welcomed for a wider understanding of the artworks.

Acknowledgements Open access funding provided by Universit $\tilde{A}$ degli Studi Roma Tre within the CRUI-CARE Agreement. Thanks to Mery Lombardi for the support in the English Language translation.

Authors' contributions All authors have contributed to the study conception and design. Material preparation, data collection and analysis were performed by Giulia Caneva, Antonella Altieri and Alma Kumbaric. The first draft of the manuscript was written by Giulia Caneva, Antonella Altieri, and Flavia Bartoli and all authors commented on previous versions of the manuscript. All authors have read and approved the final manuscript.

Funding This research did not benefit from specific funding.

Availability of data and materials All authors approve and consent for availability of data and materials.Code availability This work does not include code.

Conflicts of interest The authors declare that they have no conflict of interest.

Ethics approval All authors approve and agree on respect for ethics.

Consent to participate All authors agree to participate in the work.

Consent for publication All authors approve and consent for publication of paper.

Open Access This article is licensed under a Creative Commons Attribution 4.0 International License, which permits use, sharing, adaptation, distribution and reproduction in any medium or format, as long as you give appropriate credit to the original author(s) and the source, provide a link to the Creative Commons licence, and indicate if changes were made. The images or other third party material in this article are 
included in the article's Creative Commons licence, unless indicated otherwise in a credit line to the material. If material is not included in the article's Creative Commons licence and your intended use is not permitted by statutory regulation or exceeds the permitted use, you will need to obtain permission directly from the copyright holder. To view a copy of this licence, visit http://creativecommons.org/licenses/by/4.0/.

\section{References}

Agnoletti M, Signorini MA (2011) Il paesaggio della/The landscape of 'Cavalcata dei Magi'. Pacini, Pisa. ISBN 978-88-6315-331-6

Alessandrini A, Ceregato A (2007) Ulisse Aldovrandi. Natura picta, Compositori. ISBN 978-88-7794-490-0

Amigues S (2002) Études de botanique antique. De Boccard, Paris. ISBN 978-28-7754-130-5

Baldini E (e coll.) (1982) Agrumi, frutta ed uva nella Firenze di Bartolomeo Bimbi pittore mediceo. Consiglio nazionale delle Ricerche, Florence

Baltrušaitis J (1993) Il Medioevo fantastico: antichità ed esotismi nell' arte gotica. 2nd Ed. Mondadori, Milan

Bartolucci F, Domina G, Ardenghi NM, Bacaro G, Bacchetta G, Ballarin F, Bonari G (2019) Notulae to the Italian native vascular flora: 8. ITA Bot 8:95-116. https://doi.org/10.3897/italianbotanist .8 .48626

Baumann H (1993) Greek wildflower and plant lore in ancient Greece. Hebert Press, London

Baumann H (2000) Pflanzenbilder auf griechischen Munzen. Hirmer, Munchen

Ben-Sasson R (2012) Botanics and iconography images of the lulav and the etrog. ART JUD 8(7):7-22

Bianchi ML (1987) Signatura rerum. Segni, magia e conoscenza da Paracelso a Leibniz. Edizioni dell'Ateneo, Rome. ISBN: 978-88-2223-5442

Bonnier G (1911-1933) La grande flora. New Ed. 1990. Jaka Book, Milan

Brandi C (1972) La prima architettura Barocca di Pietro da Cortona, Borromini, Bernini. p. 123. Laterza, Rome

Caneva G (1992) Il mondo di Cerere nella Loggia di Psiche. Palombi, Roma

Caneva G (2010) Il codice botanico di Augusto-The Augustus Botanical Code. Gangemi, Roma. ISBN 978-88-492-1933-3

Caneva G, Bohuny L (2003) Botanic analysis of Livia's villa painted flora (Prima Porta, Roma). J CULT HERI 4:149-155. https://doi. org/10.1016/S1296-2074(03)00026-8

Caneva G, Carpaneto GM (2011) Raffaello e l'immagine della natura. Silvana Editoriale, Cinisello Balsamo (MI). EAN: 9788836618743

Caneva G, Dinelli A (1991) Analisi della iconografia botanica e della flora ruderale per lo studio e la conservazione della fontana di Trevi. In: Cardilli L (ed) La Fontana di Trevi-La storia, il restauro. Carte Segrete, Rome, pp 191-200

Caneva G, Pacini E, Signorini MA (2005) Finalità delle rappresentazioni botaniche nell'arte e motivi attuali d'interesse. Le rappresentazioni vegetali nella storia. In: Caneva G (ed) La Biologia vegetale per i beni culturali, vol. II Conoscenza e valorizzazione. Nardini, Florence, pp 86-114

Caneva G, Savo V, Kumbaric A (2014) Big messages of small details: nature in Roman Archaeology. Econ Bot 68(1):109-111. https:// doi.org/10.1007/s12231-013-9256-1

Caneva G, Monaco A, Virgili P, Bartoli F (2019) "Re-flowering flowers": the hope of an eternal blooming since Roman times. FLORA MEDIT 29:27-44. https://doi.org/10.7320/FlMedit29.027
Capanna E (2009) South American mammal diversity and Hernandez's Novae Hispaniae Thesaurus. Rend Fis Acc Lincei 20(1):39-60. https://doi.org/10.1007/s12210-009-0003-6

Castelli P, Aldini T, 1625. Exactissima Descriptio Rariorum Quarundam Plantarum, Que Continentur Rome in Horto Farnesiano. Romae: Typis Jacobi Mascardi

Christian M (1986) Bernini's' Danube' and Pamphilj politics. Burlington MAG 128(998):354

Clauser M, Nepi C, Signorini MA (2018) I mille fiori dell'arazzo di Pistoia. Fondazione Cassa di Risparmio di Pistoia e Pescia, Pistoia

Codex Corsinianum 167 Conto della spesa dell'opera della Guglia in Piazza Navona fatta erogare dalla Santa memoria di N. Sig.re Innocentio Decimo non compresavi però la spesa delli condotti dell'acqua. Biblioteca Corsiniana, Roma

Coggiatti S (1986) Agrumi dalla Cina in Italia e a Roma nel corso di due millenni. L'URBE 5(6):223-227

Cooke HL Jr (1956) The documents relating to the fountain of Trevi. ART BULL 38(3):149-173. https://doi.org/10.2307/3047657

D’Onofrio C (1957) Le fontane di Roma. Staderini, Roma, pp 211-212

D'Amelio MG, Marder TA (2011) Art and science in baroque Rome: Innocent X, Gianlorenzo Bernini, Athanasius Kircher, and the Four Rivers Fountain. In: Leone S (ed) The Pamphilj and the arts: patronage and consumption in baroque Rome. McMullen Museum of Art, Boston College, pp 23-36

De Naeyer AF (2019) St. Francis Basilica at Assisi (Italy) and the Detection of Medieval Geometric Design, Ratios and Modulation. Int J Archit Herit. https://doi.org/10.1080/15583058.2019.16837 77

Di Vito M (2011) Giorgio Vasari: spunti figurativi per una simbologia botanica e zoologica. Artibus ET Historiae 64:153

Donkin RA (1977) Spanish Red: An ethno-geographical study of cochineal and the Opuntia cactus. T AM Philos Soc 67(5):1-84. https ://doi.org/10.2307/1006195

Durante C (1585) Herbario nuovo di Castore Durante medico et cittadino romano, per Iacomo Bericchia et IacomoTornierij, Roma

Fabbri L (2017) Il papavero da oppio nella cultura e nella religione romana. LS Olschki, Florence. ISBN 978-88-2226-507-4

Fagiolo, M.1997. La festa barocca. 2 vols. Edizioni De Luca, Rome

Fagiolo dell'Arco M, Fagiolo dell'Arco M (1967) In Bernini: Una introduzione al gran teatro barocco. Mario Bulzoni, Roma

Fărcaş CP, Cristea V, Fărcaş S, Ursu TM, Roman A (2015) The symbolism of garden and orchard plants and their representation in paintings (I). Contributii Botanice 50:189-200

Figuier GL (1989) Storia delle piante. Messaggerie Pontremolesi, Milan

Franchi GG, Pacini E (2017) Momordica (Cucurbitaceae) types and accuracy of representation of the diagnostic characters: from Tacuinum sanitatis to American still lifes. Rend Fis Acc Lincei 28(3):569-581. https://doi.org/10.1007/s12210-017-0632-0

Frutaz AP (1962) Le piante di Roma vol. III Tavole (1693-Roma di Antonio Tempesta-Ed. G.G. De Rossi). Stabilimento Arti Grafiche Salomone, Roma

Fuchs L (1542) De historia stirpium. Isingrin Press, Basel

Galasso G, Domina G, Andreatta S, Angiolini C, Ardenghi NMG, Aristarchi C, Nepi C (2019) Notulae to the Italian alien vascular flora: 8. ITA Bot 8:63-93. https://doi.org/10.3897/italianbotanist .8 .48621

Harding A (1993) The Peony. London, Batsford ltd

Hernandez F (1648) Rerum medicarum Nouae Hispaniae thesaurus, seu Plantarum animalium mineralium Mexicanorum historia ex Francisci Hernandez... relationibus... conscriptis, a Nardo Antonio Reccho... collecta ac in ordinem digesta a Ioanne Terrentio... notis illustrata... Opus duobus voluminibus diuisum... ex typographeio Vitalis Mascardi (later reprinted in 1992)

Janick J, Caneva G (2005) The First Images of Maize in Europe. Maydica 50:1-10 
Jung CG (1983) L'uomo e i suoi simboli. Raffaello Cortina Ed, Milan

Jung CG, Kereney K (1942) Prolegomeni allo studio scientifico della mitologia. Bollati Boringhieri, Torino

Kandeler R (2006) Symbolism of plants and colours, vol 33A. Abhandlungen der Zoologisch-Botanischen Gesellschaft in Osterreich, Vienna

Kandeler R, Ulrich WR (2009a) Symbolism of plants: examples from European-Mediterranean culture presented with biology and history of art. J Exp Bot 60(2):353-355. https://doi.org/10.1093/jxb/ erp012

Kandeler R, Ulrich WR (2009b) Symbolism of plants: examples from European-Mediterranean culture presented with biology and history of art. J Exp Bot 60(3):715-717. https://doi.org/10.1093/jxb/ erp041

Kandeler R, Ulrich WR (2009c) Symbolism of plants: examples from European-Mediterranean culture presented with biology and history of art. J Exp Bot 60(4):1067-1068. https://doi.org/10.1093/ jxb/erp042

Kandeler R, Ulrich WR (2009d) Symbolism of plants: examples from European-Mediterranean culture presented with biology and history of art. J Exp Bot 60(6):1535-1536. https://doi.org/10.1093/ jxb/erp087

Kandeler R, Ulrich WR (2009e) Symbolism of plants: examples from European-Mediterranean culture presented with biology and history of art. J Exp Bot 60(7):1893-1895. https://doi.org/10.1093/ jxb/erp088

Kandeler R, Ulrich WR (2009f) Symbolism of plants: examples from European-Mediterranean culture presented with biology and history of art. J Exp Bot 60(9):2461-2464. https://doi.org/10.1093/ jxb/erp166

Kandeler R, Ulrich WR (2009g) Symbolism of plants: examples from European-Mediterranean culture presented with biology and history of art. J Exp Bot 60(11):2955-2956. https://doi.org/10.1093/ jxb/erp207

Kandeler R, Ulrich WR (2009h) Symbolism of plants: examples from European-Mediterranean culture presented with biology and history of art. J Exp Bot 60(12):3297-3299. https://doi.org/10.1093/ jxb/erp247

Kandeler R, Ulrich WR (2009i) Symbolism of plants: examples from European-Mediterranean culture presented with biology and history of art. J Exp Bot 60(13):3611-3613. https://doi.org/10.1093/ jxb/erp215

Kandeler R, Ulrich WR (2009j) Symbolism of plants: examples from European-Mediterranean culture presented with biology and history of art. J Exp Bot 60(15):4219-4220. https://doi.org/10.1093/ jxb/erp266

Kircher A (1650) Obeliscus Pamphilius. Lodovico Grignani, Rome

Kircher A (1678) Mundus Subterraneous. 2 Vols. Joannem Jansonsium a Waesberge \& Filios, Amsterdam

Koehn A (1952) Chinese flower symbolism. MON NIP 8(1/2):121-146

Kumbaric A, Caneva G (2014) Updated floristic biodiversity of Roman iconography. Rend Fis Acc Lincei 25(2):181-193. https://doi. org/10.1007/s12210-013-0279-4

Kumbaric A, Savo V, Caneva G (2013) Orchids in the Roman iconography: evidence for the first representations. Int J Cult Herit 14(4):311-316. https://doi.org/10.1016/j.culher.2012.09.002

Levi D'Ancona M (1977) The Garden of the Renaissance. Botanical Symbolism in Italian paintings. Leo S, Olschki

Mangiavacchi M, Pacini E (2002) Arte e Natura in Toscana: gli elementi naturalistici e il paesaggio negli artisti deal Trecento al Cinquecento. Pacini, Pisa

Matthioli PA (1565) (MDLXV)-Commentarii in sex libros Pedacii dioscoridis Anazarbei de Medica materia. Ex Officina Valgrisiana

Mattirolo O (1911) I vegetali nell'arte degli antichi e dei primitivi. Paravia, Torino
Metusala D, DA Fauziah Lestari, Damaijani J, Mas'udah S, Setyawan H (2020) The identification of plant reliefs in the Lalitavistara story of Borobudur temple, Central Java, Indonesia. Biodiv 21(5):22062215. https://doi.org/10.13057/biodiv/d210549

Moggi G (1982) Piante e fiori della Primavera. In: Baldini U (ed) Metodo e scienza operatività e ricerca nel restauro. Sansoni, Florence, 23 giugno 1982-6 gennaio 1983

Moggi G (1987) Le piante nella pittura italiana dei secoli XV e XVI: problemi e metodi di identificazione botanica. In: Jahrhundert Prinz W, Beyer A (eds) Die Kunst und das Studium der Natur vom 14. Zum 16. Acta humaniora, Weinheim

Mosco M, Rizzotto M (1988) Floralia: florilegio dalle collezioni fiorentine dei Sei-Settecento. Centro Di, Florence

Nepi C, Signorini MA (2015) L’Allegoria della Virtù: l'erbario di Ligozzi. In: De Luca F., Onali M (eds) La Virtù del Principe, L'Allegoria di Jacopo Ligozzi. Gli Uffizi Studi e Ricerche, Florence, pp 30: 70-75

Pacini E (1988) Dalla parte del Botanico. In: Mosco M, Rizzotto M (eds) Floralia: florilegio dalle collezioni fiorentine dei Sei-Settecento. Centro Di, Florence, pp 19-22

Pacini E (1995) Purposes and manners of representation of plants in the European art of XIV-XVII centuries. In: Dgfinn M, Dickson J, Joergensen PM (eds) Garden history, garden plants, species, forms, and varieties from Pompei to 1800. PACT J 42: $172-179$

Pandolfi A (2012) La Fontana Dei Fiumi in Piazza Navona: Gli interventi conservativi sull'obelisco Pamphilj-Il piano di manutenzione. Gangemi Editore, Rome

Parkinson J (1629) Paradisi in Sole Paradisus Terrestris. Arkose Press. ISBN-10: 1345111320

Pavesi M (2010) Un nuovo" San Giovanni Battista nel deserto" della fase caravaggesca di Giuseppe Vermiglio. Arte Lombarda 160(3):14-19

Pignatti S (2019) Flora d'Italia, 4 voll., 2nd Ed. Edagricole, Milan

Pignatti S, Cipriani M (2010) The diversity of plants in a text from the seventeenth century. Rend Fis Acc Lincei 21:343-350. https://doi. org/10.1007/s12210-010-0105-1

Plinius GS (1985) Naturalis historia. Voll III, Einaudi

Preimesberger R (1974) Obeliscus Pamphilius, Beiträge zu Vorgeschichte und Ikonographie des Vierströmebrunnens auf Piazza Navona. In: Münchner Jahrbuch der bildenden Kunst, Munchen: Knorr \& Hirth Prestel

Ripa, C. 1603. Iconologia (Vol. 3). Lepido Faci, Rome

Rowland I (2001) "The United Sense of the Universe": athanasius Kircher in Piazza Navona. MEM A ACAD R 46:153-181. https ://doi.org/10.2307/4238784

San Juan RM (2012) The transformation of the Río de la Plata and Bernini's fountain of the four rivers in Rome. Represent 118(1):72-102. https://doi.org/10.1525/rep.2012.118.1.72

Savo V, Kumbaric A, Caneva G (2016) Grapevine (Vitis vinifera L.) Symbolism in the Ancient Euro-Mediterranean culture. Notes on Economic Plants. ECON BOT 70 (2): 190-197. https://doi. org/10.1007/s12231-016-9347-x

Sgamellotti A, Caneva G (2017) I colori della prosperità: frutti del vecchio e del nuovo mondo. Catalogo della mostra (Roma, 20 aprile-20 luglio 2017). ITALIANO-ENGL. Bardi, Rome. EAN: 9788894810080

Shepard NL (2012) Everlasting ephemera: temporary festival structures and Bernini's Fountain of the Four Rivers. MA (Master of Arts) thesis, University of Iowa. https://doi.org/10.17077/etd.qms85oda

Signorini MA, Zucchi V (2018) La natura dipinta. Piante, fiori e animali nelle rappresentazioni di Palazzo Vecchio a Firenze. IGR Grafiche-Aboca, Sansepolcro

Signorini MA, Pacini E, Nepi C (2011) I misteriosi 'alberi delle meduse' di Guido da Siena, pittore toscano del XIII secolo. Un contributo di botanica applicata ai beni culturali. INF BOT ITA 43(1):65-73 
Signorini MA, Pacini E, Agnoletti M (2017) Piante, fiori, simboli. L'elemento vegetale nell'iconografia dei Magi attraverso gli esempi di Gozzoli e Gentile da Fabriano. In: Bedini A, Macchia G, Ognibene P, Panaino A, Piras A (eds) La luce della stella: I Re Magi fra arte e storia Indo-iranica et orientalia. Mimesis, Milan, pp17: 91-118. ISBN: 9788857542768

Simonetta G, Gigli L, Marchetti G (2003) Sant'Agnese in Agone a Piazza Navona. Bellezza proporzione armonia nelle fabriche Pamphili, Gangemi
The Plant List (TPL) 2013. http://www.theplantlist.org. Version 1.1

Publisher's Note Springer Nature remains neutral with regard to jurisdictional claims in published maps and institutional affiliations. 